\title{
Intraoperative Length and Tension Curves
}

\section{of Human Eye Muscles}

\author{
Including Stiffness in Passive Horizontal Eye Movement \\ in Awake Volunteers
}

Huibert J. Simonsz, MD, PhD; Gerold H. Kolling, MD, PhD;

Herbert Kaufman, MD, PhD; Bob van Dijk, $\mathrm{PhD}$

\begin{abstract}
- Intraoperative continuous-registration length and tension curves of attached and detached eye muscles were made in 18 strabismic patients under general anesthesia. For relaxed eye muscles, we found an exponential relation between length and tension. An increased stiffness was quantified in Duane's syndrome, Graves' disease, orbital-floor fracture, and superior oblique palsy. The stiffnesses of agonist and antagonist were remarkably similar, not only in uncomplicated squint, but also when only one of the two had initially become stiffer. After intravenous administration of succinylcholine chloride, the eye muscles contracted, and the exponential length and tension curve changed into a set of straight, parallel lines. In addition, we measured stiffness in passive horizontal eye movement in awake volunteers and found 0.52 to $1.26 \mathrm{~g}$ /degrees (other eye in $5^{\circ}$ of adduction), confirming other published results.
\end{abstract}

(Arch Ophthalmol 1986;104:14951500)

Tength and tension characteristics of 1 isolated, human eye muscles have been assessed by Collins et al $^{1,2}$ and Robinson et al. ${ }^{3}$ In these experiments, a suture from the lateral rectus tendon, which was detached from the eye

Accepted for publication Jan 23, 1986.

From the Augenklinik für Schielbehandlung und Neuroophthalmologie, Klinikum der JustusLiebig-Universität, Giessen, West Germany (Drs Simonsz, Kolling, and Kaufman); and the Netherlands Ophthalmic Research Institute, Amsterdam (Dr van Dijk).

Reprints not available. during strabismus surgery (under local anesthesia), was fastened to a strain gauge to measure force. The gauge was moved 2,5 , and $8 \mathrm{~mm}$ either way from an estimated primary-position length with a worm gearing between measurements to change muscle length. The patient changed innervation to the eye muscles by looking left and right at target lamps over the surgery table, using the other eye. Yet a problem remained. In the three lateral rectus muscles that were measured under local anesthesia, ${ }^{3}$ the stiffness of the muscle around the estimated, primary-position length amounted to approximately $0.7 \mathrm{~g} /$ degrees. Extrapolating these data, the total stiffness for moving the globe passively in a nasal or temporal direction should exceed $1.4 \mathrm{~g} /$ degrees, as the stiffness of the adnexa of the globe should be added to the two stiffnesses of lateral and medial rectus muscles.

This differs from later experiments, ${ }^{1}$ in which, in 29 volunteers, one eye was abducted or adducted from $30^{\circ}$ of adduction to $30^{\circ}$ of abduction (or vice versa), by grasping the limbus with a forceps equipped with a strain gauge and an ultrasound distancemeasuring device, while the other eye maintained fixation. In those experiments, total horizontal stiffness averaged $0.99 \mathrm{~g} /$ degrees (range, 0.77 to 1.40 g/degrees). Moreover, we recently reported on measurements of stiffness in passive cyclotorsion in eight volunteers, in which the eye was grasped with a perilimbal vacuum contact ring, mounted on a shaft equipped with an eddy-current motor and a shaft-position encoder. ${ }^{4.5}$ We found $0.55 \mathrm{~g} /$ degrees (range, 0.4 to 0.66 $\mathrm{g} /$ degrees) for stiffness in passive cyclotorsion. This also differs from the above-mentioned amount.

For analysis of strabismus surgery, we use the Robinson ${ }^{6}$ computer model. The performance of the model has been improved by us, using a wide range of anatomical, experimental, and clinical data. ${ }^{7}$ Because uncertainty about the mechanical properties of eye muscles was a disturbing factor in the performance of the model, as mentioned above, we made intraoperative continuous-registration length and tension curves of attached and detached human eye muscles in patients under general anesthesia for strabismus surgery. The measurements were repeated in some patients after administration of succinylcholine chloride and curare. In addition, we measured the stiffness in passive horizontal globe rotation in awake volunteers.

Quantified force-duction tests have been assessed previously. ${ }^{8-16}$ No method, however, used continuous registration, which made it impossible to quantify the hysteresis. Moreover, most of the measurements were in the upper force range, up to $100 \mathrm{~g}$, while the tension in eye muscles is between 5 and $20 \mathrm{~g}$ most of the time. At lower force levels, the disturbance of the measurements by hysteresis becomes more prominent. In addition, the rotation of the eye was assessed by not very accurate methods, making a resolution of $1^{\circ}$ (equal to $0.205 \mathrm{~mm}$ on the 
Table 1.-Data in 18 Strabismic Patients *

\begin{tabular}{|c|c|}
\hline $\begin{array}{l}\text { Patient/ } \\
\text { Age, } \\
\text { y/Eye }\end{array}$ & $\begin{array}{l}\text { Diagnosis and } \\
\text { Angles of Squint }\end{array}$ \\
\hline $1 / 26 /$ Left & Conv: far, $+17^{\circ} ;$ near, $+17^{\circ}$ \\
\hline 2/39/Left & $\begin{array}{l}\text { Conv: far, }+12^{\circ} \text {; near, } \\
+20^{\circ} \text {; right eye previous } \\
\text { rec and res for conv (far, } \\
+12^{\circ} \text {; near, }+20^{\circ} \text { ) }\end{array}$ \\
\hline 3/31/Right & Conv: far, $+15^{\circ} ;$ near, $+17^{\circ}$ \\
\hline 4/20/Left & Conv: far, $+20^{\circ}$; near, $+22^{\circ}$ \\
\hline $5 / 20 /$ Left & Conv: far, $+25^{\circ} ;$ near, $+25^{\circ}$ \\
\hline $6 / 25 /$ Left & $\begin{array}{l}\text { Decompensated exoph: far, } \\
-20^{\circ} \text {; near, }-20^{\circ}\end{array}$ \\
\hline 7/39/Right & $\begin{array}{l}\text { Decompensated exoph: far, } \\
-10^{\circ} \text {; near, }-12^{\circ}\end{array}$ \\
\hline $8 / 35 /$ Left & Div: far, $-29^{\circ} ;$ near, $-29^{\circ}$ \\
\hline $9 / 23 /$ Left & Div: far, $-22^{\circ} ;$ near, $-25^{\circ}$ \\
\hline $10 / 25 /$ Left & Div: far, $-12^{\circ}$; near, $-15^{\circ}$ \\
\hline $11 / 20 /$ Left & Div: far, $-12^{\circ} ;$ near, $-12^{\circ}$ \\
\hline $12 / 40 /$ Right & $\begin{array}{l}\text { Conv: }+2^{\circ}, \text { VD: }+2^{\circ}, \\
\text { sursoadd, DVD; previous } \\
\text { surgery: rec and res for } \\
\text { conv (right eye), rec of } \\
\text { superior oblique and } \\
\text { tenotomy of medial rectus } \\
\text { (left eye) }\end{array}$ \\
\hline 13/25/Left & $\begin{array}{l}\text { Left Duane, decompensated } \\
\text { exoph: }-4^{\circ} ; \text { left eye } \\
\text { previous rec of lateral } \\
\text { rectus }\end{array}$ \\
\hline $14 / 62 /$ Left & Bilateral Graves, VD: $+12^{\circ}$ \\
\hline 15/35/Right & $\begin{array}{l}\text { Right superior oblique palsy; } \\
1963 \text { accident }(\text { coma); } \\
\text { torticollis; VD: }+12^{\circ} \text {, on } \\
\text { right/left gaze: }+4 /+18^{\circ} \text {, } \\
\text { Bielschowsky: }+3 /+15^{\circ} \\
\text { excyclo: }+2^{\circ}\end{array}$ \\
\hline 16/63/Right & $\begin{array}{l}\text { Right orbital floor fracture } 6 \\
\text { months previously; VD: } \\
-7^{\circ}\end{array}$ \\
\hline $17 / 8 /$ Left & $\begin{array}{l}\text { Left Duane, decompensated } \\
\text { exoph: }-20^{\circ} ; \text { previous } \\
\text { bilateral rec of lateral recti }\end{array}$ \\
\hline $18 / 30 /$ Left & $\begin{array}{l}\text { Left superior oblique palsy; } \\
1978 \text { accident (coma); } \\
\text { torticollis; VD: }-13^{\circ} \text {, on } \\
\text { right/left gaze: }-19 /-7^{\circ} \text {, } \\
\text { Bielschowsky: }-20 /-1^{\circ} \text {; } \\
\text { excyclo: }+10^{\circ}\end{array}$ \\
\hline
\end{tabular}

Eye indicates the operated and measured eye which is not necessarily the squinting eye; exoph, exophoria; conv, convergence; div, divergence; VD, vertical divergence (negative operation sign indicates left hypertropia); rec, recess surgery; res, resect surgery; Bielschowsky, VDs in Bielschowsky head-tilt test; sursoadd, strabismus sursoadductorius (elevation in adduction); far, angle of squint at far, using alternating cover test; near, angle of squint at near. using alternating cover test; excyclo, excy. clotropia; Duane, Duane's syndrome; Graves, Graves' disease; and DVD, dissociated vertical deviation. circumterence of the average globe) unlikely. An exception is the abovementioned method of Collins et al.'

\section{PATIENTS AND METHODS}

Measurements were performed in 18 patients. Essential patient data are given in Table 1. During surgery, a length-and tension measuring device was fixed rigidly above the head of the patient. This measuring device was described previously. ${ }^{4.5}$ Briefly, it consisted of a $2-\mathrm{mm}$ hardened steel shaft, suspended by precision minute ball bearings and equipped with a shaftposition encoder and an eddy-current motor. The torque generated by the eddycurrent motor in the shaft and the position of the shaft could be assessed electronically. The frame on which it was mounted consisted of $30-\mathrm{mm}$ steel posts fixed to the railing of the operating table, a $20-\mathrm{mm}$ steel traverse bar above the chest of the patient, and a $20-\mathrm{mm}$ steel bar that could be clamped tight in any position rectangular to the traverse bar. The position of the part of the shaft that stuck out of the measuring device was in line with the muscle to be measured in case of a detached muscle. When the muscle was also measured while still attached to the globe, a place was chosen that ensured that the suture connecting shaft and insertion was tangent to the globe during the larger part of the measurement. In measurements of the oblique muscles, the head of the patient was rotated contralaterally, and the device was positioned such that the muscle was pulled on in a frontal plane. The head of the patient was fixed rigidly on the circular cushion of the steel head support by a wide silk plaster around the patient's forehead.

A 4-0 silk suture was passed through one of the muscles to be measured and wrapped around the shaft with a tight knot. Then the torque generated in the shaft was slowly (longer than $45 \mathrm{~s}$ either way) increased and decreased, exerting a pull that varied between 0 and $40 \mathrm{~g}$. The procedure was then repeated after the muscle was separated from the globe. The primary-position length could only be estimated reliably in the attached muscle, comparing the positions of the two eyes (we used a transparent drape). Accurate estimation of the primary-position length after separation from the globe proved to be impossible.

All patients received 6 to $14 \mathrm{mg}$ of alcuronium chloride (a nondepolarizing muscle relaxant that works for $\sim 30$ minutes) at the beginning of the halothane anesthesia, approximately 20 minutes before the measurements. To clarify whether any contraction remained under these conditions, $4 \mathrm{mg}$ of vecuronium bromide (Norcuron), a short-acting nondepolarizing muscle relaxant, was injected intravenously between two sets of two identical measurements in patient 10 . In patients 5,9 , and 11 , we repeated the measurements at various intervals after intravenous injection of succinylcholine chloride (a short-acting depolarizing muscle relaxant), $1 \mathrm{mg} / \mathrm{kg}$ of body weight; in patient 11 only, a dosage of
$2 \mathrm{mg} / \mathrm{kg}$ of body weight had been given 30 minutes previously.

In eight awake volunteers, stiffness in passive horizontal eye movement was measured by letting the measuring device pull a 4-0 silk suture, fixed to the edge of a perilimbal vacuum contact ring and tangential to the globe. The vacuum contact ring has been desseribed previously. ${ }^{4.5}$ The eye to be measured was pulled temporally while the subject fixated a fixation-mark with the other eye, which was in $5^{\circ}$ of abduction. Hence, the eye to be measured was pulled from $5^{\circ}$ of adduction to about $20^{\circ}$ abduction. An xy-recorder (HewlettPackard 7035BXY) was used.

As the diameter of the silk suture was $0.16 \mathrm{~mm}$ and the diameter of the shaft was $1.998 \mathrm{~mm}$, the effective radius was assumed to be $1.08 \mathrm{~mm}$. The shaft-position encoder has been described previously. 4.5 The disk of the shaft-position encoder had 1000 radial lines, and the digital counter ran from 1 to 256. Hence, one complete count equaled $92^{\circ}$ shaft rotation or $2 \times \pi \times 256 / 1000 \times 1.08=1.737 \mathrm{~mm}$ muscle lengthening. Although the calibration of the distance measured was thus very easy, the resulting curves were difficult to read. We therefore decided to redraw the curves, transferring values found at 1.737 $\mathrm{mm}$ intervals or half of that interval if necessary. Calibration of the force generated in the disk of the eddy-current motor was as described previously. 4.5

The small errors resulting from the weight of the suture and the muscle were disregarded. To check for displacement of the measuring device, we let the device pull on an extra-long silk suture fixed to the steel head support, at full bar extension, which was about 1.5 times the extension used in the experiments. The displacement of the device and the stretch of the silk suture together were $0.8 \mathrm{~mm}$ at $40 \mathrm{~g}$.

For conversion of millimeters to percentage of muscle-length change and to degrees of eye rotation, the data of Lang et $\mathrm{al}^{17}$ were used. They found that the average transverse diameter of the eye was 23.42 $\mathrm{mm}$, and the muscle length was about 37 $\mathrm{mm}$ (without tendon) for all rectus muscles. Thus, 1-mm muscle-length change equals $4.89^{\circ}$, and $1 \%$ muscle-length change equals $1.81^{\circ}$. The data of Lang et al ${ }^{17}$ were also used in the computer model.

\section{RESULTS}

A sample of two of the patients with uncomplicated convergent and divergent squint is depicted in Fig 1. The hysteresis is much larger in the measurement of the attached muscle because of the starting and sliding friction between globe and adnexa. Hysteresis is defined here as half of the vertical difference between the ascending and the descending limb of a curve at any one point, equal to the tension needed to overcome the sliding friction. As the measurements were performed very slowly, it seems reasonable to assume that the hysteresis consisted predominately of slid- 

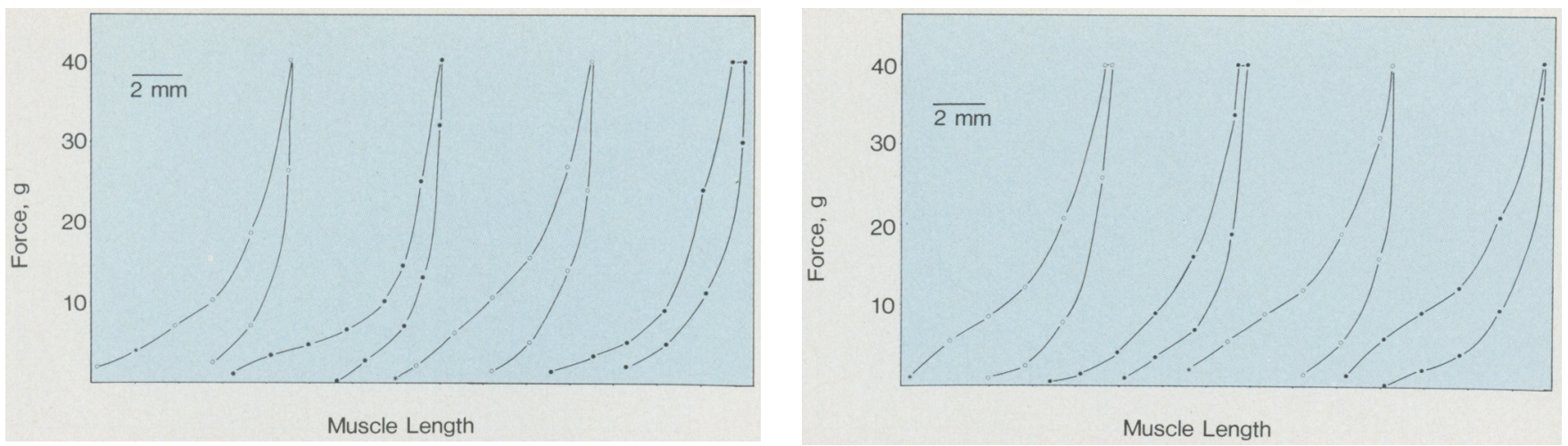

Fig 1. - Length and tension curves of four horizontal eye muscles. Although scale is identical in all four figures, absolute muscle-length values do not correspond in Figs 1 to 4 , unless otherwise stated; traces are set side by side only for comparison. Each curve is composed of left limb (force increase) and right limb (force decrease). Open circles indicate attached muscles; solid circles, detached muscles; and asterisks, primary position, assessed for attached muscles only. Left, Patient 4. Medial rectus (left pair of curves) and lateral rectus (right pair of curves) muscles. Right, Patient 7. Lateral rectus (left pair of curves) and medial rectus (right pair of curves) muscles.

ing friction. The hysteresis was reasonably constant during any one measurement, reflecting the constancy of the sliding friction.

To get an impression of the spread of the curves, all curves of detached medial and lateral rectus muscles of patients 1 to 11 were superimposed through an arbitrarily chosen common point at which the force was $20 \mathrm{~g}$ (Fig 2, top). The similarity in stiffness of medial and lateral rectus muscles was remarkable. Stiffness is defined as the average slope of the curve. The average of all curves could be approached, after subtraction of the hysteresis $(3.25 \mathrm{~g}$, average, in the detached muscles), with an exponential equation, which would be as follows for these 11 patients with uncomplicated convergent and divergent squint, assuming a muscle length of 37 mm (Fig 2 , center):

Tension $=0.7914 \times\left(e^{0.1526 \times \% \text { Change in Length }}-1\right)$

We found only a slight difference between the two sets of curves of patient 10, obtained before and after injection of vecuronium - less than 0.4 $\mathrm{mm}$ (Fig 2, bottom). The ascending limb of the first curve was on the left-hand side in the group of four curves; maybe the muscle yielded during the first measurement. Figure 3, top, shows the curves that we obtained from inferior rectus muscles in patients with convergent squint, orbital floor fractures, and Graves' disease. Figure 3, center and bottom, shows the curves that we obtained in patients with Duane's syndrome (lateral and medial rectus muscles) and superior oblique palsy (superior and inferior oblique muscles). The very large hysteresis in the measurements of the oblique muscles is conspicuous. The remaining two patients with Duane's syndrome and superior oblique palsy had curves similar to the two patients shown.

In patients 5,9 , and 11 , succinylcholine chloride, $1 \mathrm{mg} / \mathrm{kg}$ of body weight, was administered intravenously between measurements. The resulting contraction shifted the curve to the left of the diagram and changed it into a set of almost straight, parallel lines (Fig 4). The slopes of these lines were similar for lateral and medial rectus muscles in each patient. The constant slope value was $0.35 \mathrm{~g} /$ degrees in patients 5 and 9 and 0.5 $\mathrm{g} /$ degrees in patient 11 . Only patient 11 had received succinylcholine chloride, $2 \mathrm{mg} / \mathrm{kg}$ of body weight, at intubation.

In passive horizontal eye movement, we found a linear relation between tension and eye rotation in all volunteers. The constant slope values, however, differed considerably in each volunteer (Table 2).

\section{COMMENT}

We found an exponential relation between length and tension of relaxed human eye muscles. Many collagenous tissues, including skeletal muscle, skin, mesentery, and sclera, obey similar exponential relationships between length and tension. ${ }^{18-20}$ The exponential curves for lateral and medial rectus muscles in convergent and divergent squint were almost identical, which is not consistent with the general principle that a thicker and shorter muscle (medial rectus, in this case) should be proportionately stiffer. The hysteresis (as defined in the "Results" section) that we found in measurements of attached muscles was much larger than in detached muscles. This means that the friction of the eye in the orbit is considerable. Most of this will be sliding friction, but there may also be some starting friction. In dynamic modeling of saccades, this should be taken into account. The great friction that we found in the oblique muscles was most likely caused by pulling on the muscle in a frontal plane, which is tilted to the muscle plane of the obliques by an average of $39^{\circ}$.

The measurements in patient 10 confirm that the muscles were fully relaxed by alcuronium chloride and halothane anesthesia. This finding depreciates the arguments of those whose surgery is guided by the eye position or eye movements of strabismic patients under general anesthesia, although there may be differences in the anesthetics used. Halothane enhances the muscle relaxation achieved by alcuronium chloride.

The increase of stiffness in patients 12 to 18 , who suffered from Graves' disease, orbital floor fracture, Duane's syndrome, and superior oblique palsy, was according to our expectations. In the patients with superior oblique palsy, the muscle may have gotten stuck in the trochlea during the measurement, or adhesions between trochlea and tendon may have been present. In all stiffer muscles, we found antagonists to be almost equally stiff. It appears that agonist and antagonist have similar stiffnesses not only under normal conditions but also when the stiffness of only one of the two is changed initially by a disease process. The malfunction- 


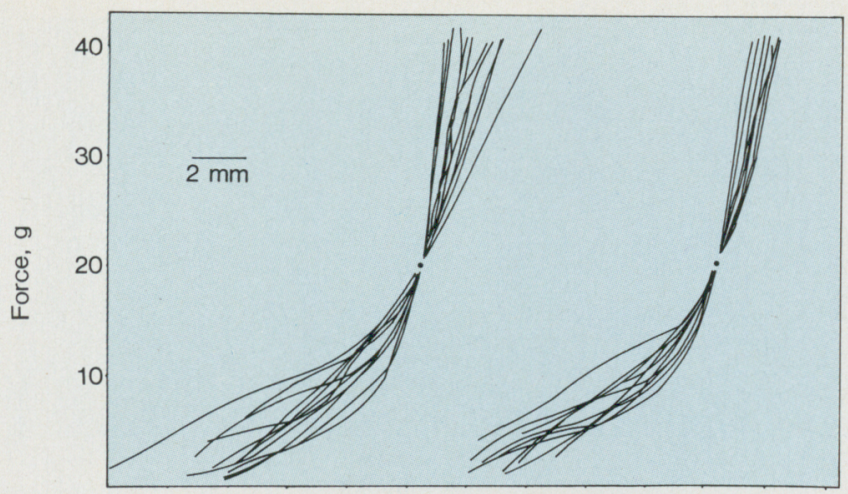

Muscle Length

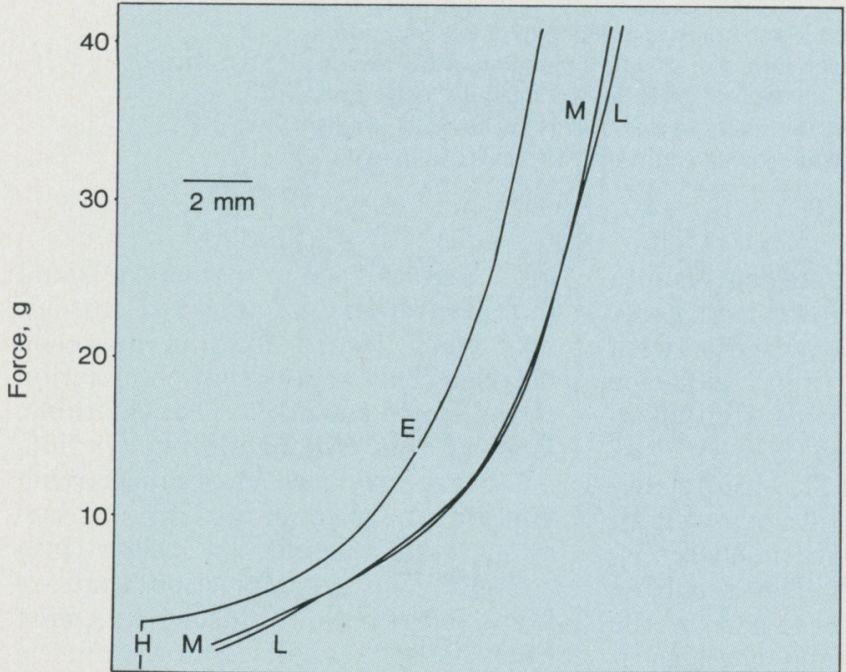

Muscle Length

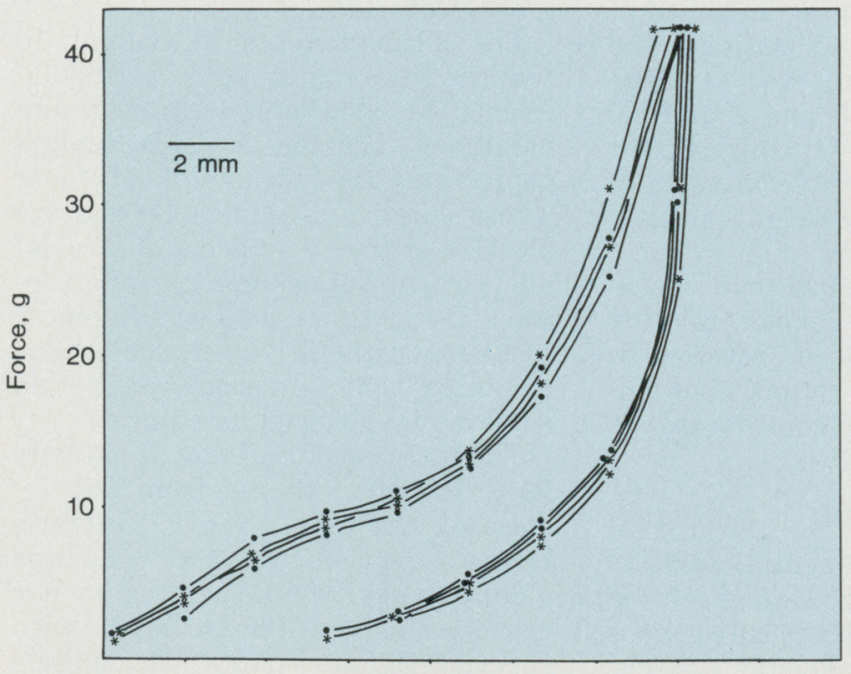

Muscle Length

Fig 2. - Top, All left limbs of curves of detached lateral rectus (left) and medial rectus (right) muscles of patients 1 to 11 were superimposed through arbitrarily chosen common point (solid circles) at which force was $20 \mathrm{~g}$. Center, Estimated averages of all detached lateral $(\mathrm{L})$ and medial $(M)$ rectus muscles were superimposed. After subtracting average hysteresis $(H)$, equal to half of vertical distance between left and right limbs (3.25 g), curves were approximated with exponential function (E). Bottom, Patient 10. Two curves were made before (asterisks) and two curves after (solid circles) injection of $4 \mathrm{mg}$ of vecuronium bromide. Calibration is as in Fig 1 .

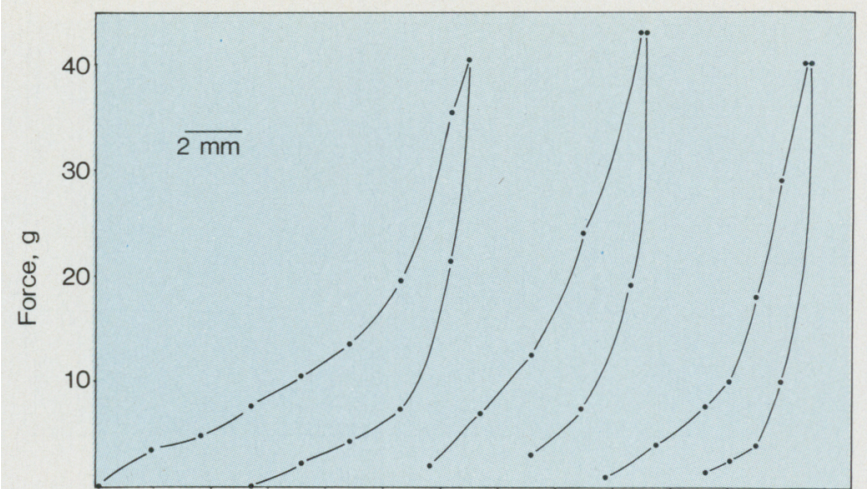

Muscle Length

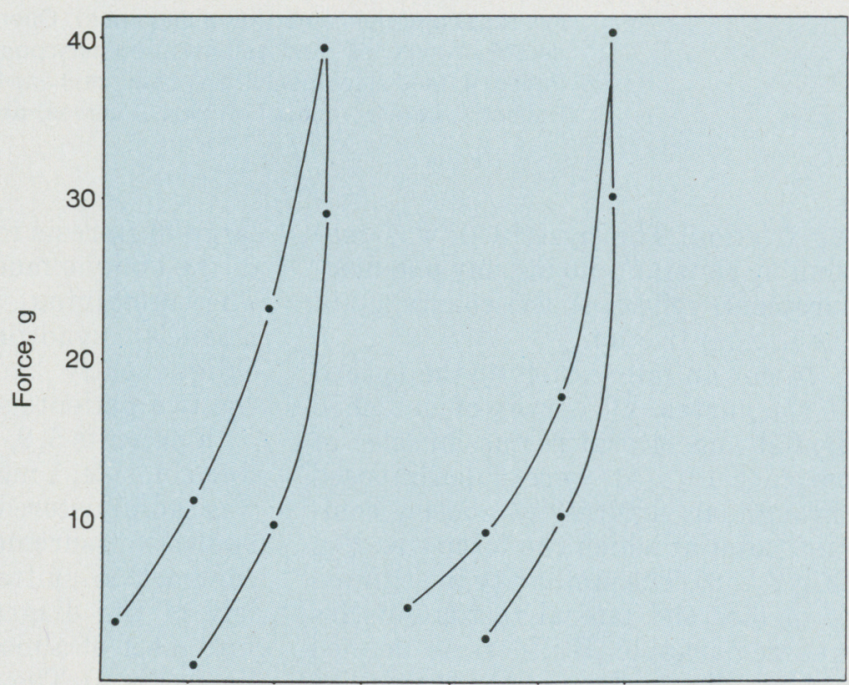

Muscle Length

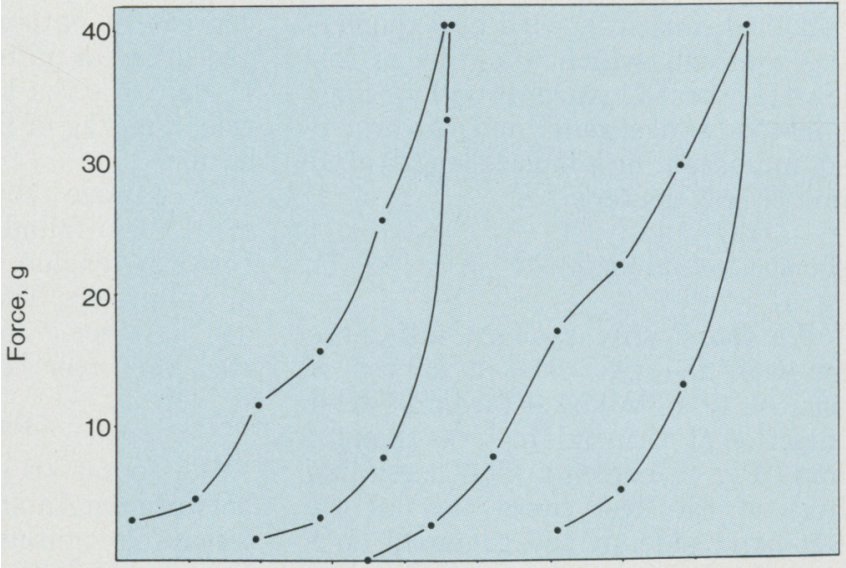

Muscle Length

Fig 3. - Top, Length and tension curves of detached inferior rectus muscles of patients 12 (left curve), 16 (middle), and 14 (right), with convergent squint, orbital floor fracture, and Graves' disease, respectively. Note increased stiffness in patients suffering from orbital floor fracture and Graves' disease. Center, Lateral rectus (left curve) and medial rectus (right) muscles of patient 17, suffering from Duane's syndrome. Bottom, Inferior oblique (left curve) and superior oblique (right) muscles of patient 18. Increased stiffness of superior oblique may have been caused by adhesions to trochlea or by muscle being stuck in trochlea, that of inferior oblique by contracture. Calibration is as in Fig 1. 


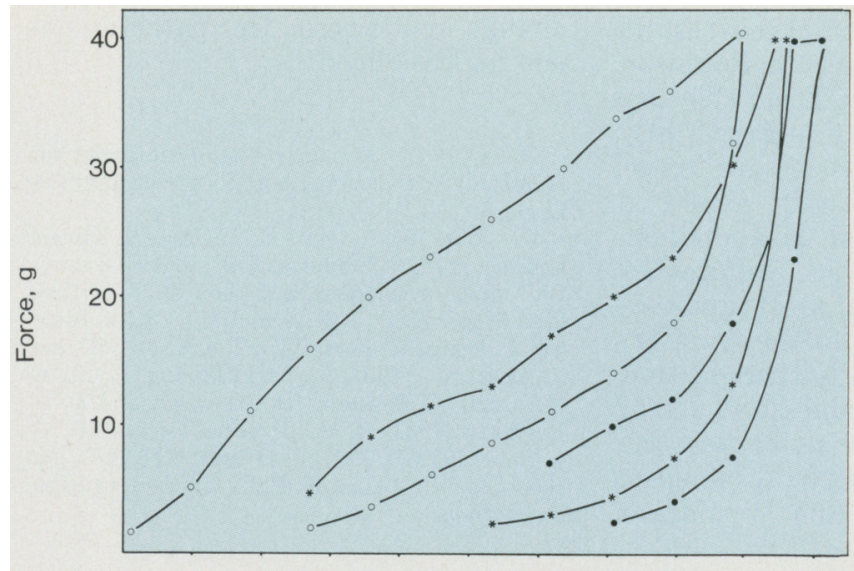

Muscle Length

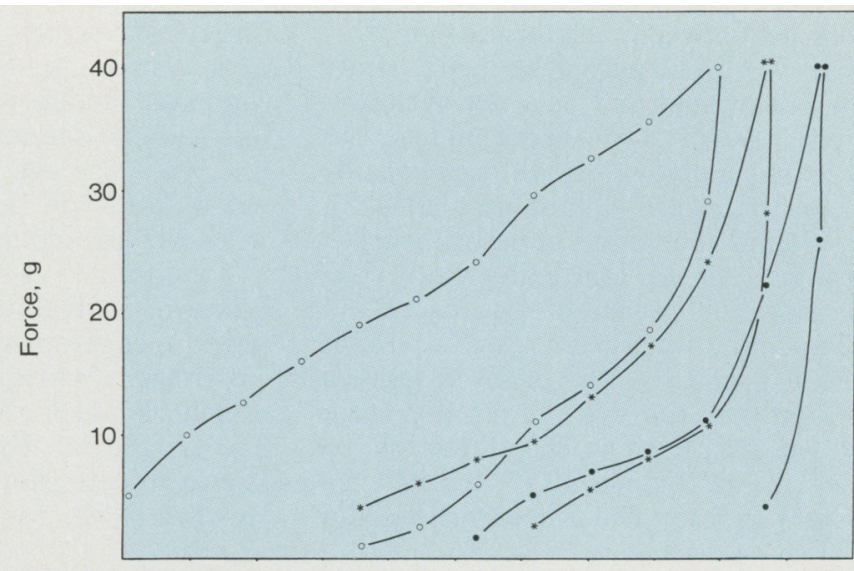

Muscle Length

Fig 4. - Lateral rectus (left) and medial rectus (right) muscles of patient 5 . In these two diagrams, muscle-length values correspond for each set of three curves. Solid circles indicate before intravenous injection of succinylcholine chloride, $1 \mathrm{mg} / \mathrm{kg}$ of body weight; open circles, one minute after injection; and asterisks, six minutes after injection. In first measurement after administering succinylcholine chloride, seemingly larger hysteresis is partly caused by diminishing action of succinylcholine chloride. Calibration is as in Fig 1.

\begin{tabular}{|cc|}
\hline $\begin{array}{c}\text { Table 2. - Stiffness in Passive } \\
\text { Horizontal Rotation of Eyes } \\
\text { in Eight Awake Volunteers }\end{array}$ \\
\hline Subject & \multicolumn{1}{c|}{ Stiffness, g/Degrees } \\
\hline 1 & $\begin{array}{c}1.06 \mathrm{OD} ; 1.26 \text { OS (1 wk later); } \\
\text { 1.03 OD } \dagger\end{array}$ \\
2 & $0.53 \mathrm{OD} ; 0.52 \mathrm{OD}$ (1 wk later); \\
3 & $0.74 \mathrm{OS}$ \\
4 & $0.71 \mathrm{OD}$ \\
5 & $0.88 \mathrm{OD}$ \\
6 & $0.82 \mathrm{OD}$ \\
7 & $1.18 \mathrm{OD}$ \\
8 & $1.18 \mathrm{OD}$ \\
\hline
\end{tabular}

- Stiffness is defined as the ratio between force and eye rotation (the relationship was linear in all volunteers).

tSubject 1 had an exophoria, and the final measurement in the right eye was taken after one eye was patched for two days.

ing of the affected agonist causes lack of movement in the antagonist, resulting in a secondary contracture with a stiffness similar to the stiffness of the primarily affected muscle.

Acetylcholine chloride and succinylcholine chloride cause contraction of extraocular eye muscles ${ }^{21 \cdot 25}$ by preferentially stimulating multiply innervated muscle fibers, a common type of muscle fiber in lower vertebrates but seen in mammalians only in the extraocular eye muscles. There are two kinds of multiply innervated muscle fibers. Amphibian-type multiply innervated fibers (type 6 in the report by Asmussen et al ${ }^{26}$; type 4, Alvarado and van Horn $^{27}$; and type I, Brooke and Kaiser ${ }^{28}$ ) contract by local depolariza- tion of the cell membrane in the proximity of one of the multiple $(\approx 20)$ end plates. ${ }^{24}$ Avian-type multiply innervated fibers (type 2, Asmussen et al; type 5, Alvarado and van Horn; and type I, Brooke and Kaiser) display slow ( $7 \mathrm{~ms}$ ) monophasic electromyographic potentials, representing abortive action potentials. ${ }^{29}$ They have about six end plates. According to Asmussen et al, type 2 is seen in the orbital part of the muscle, is about 10 $\mu \mathrm{m}$ diameter, and has many mitochondria, and type 6 is seen in the central and global parts of the muscle, is about $20 \mu \mathrm{m}$ diameter, and has scanty mitochondria. Gornig et al ${ }^{30}$ were able to demonstrate that the slow monophasic potentials are the first to appear, when muscle activity is increased from relaxation onward. They registered electromyographic activity in the superior oblique and superior rectus muscles in rabbits subjected to progressively tilted positions. Their finding means that these fibers are active most of the time, in contrast to the thick, global fibers with scanty mitochondria (types 3 and 4, Asmussen et al; types 1 and 2, Alvarado and van Horn; and type IIB, Brooke and Kaiser) that are used for short periods during saccades. Multiply innervated muscle fibers are served by smaller (about $5 \mu \mathrm{m}$ ) and slower ${ }^{31}$ nerve fibers compared with those serving singly innervated fibers (about $11 \mu \mathrm{m}$ ). ${ }^{32}$ The motor-unit size is smaller - three to four fibers for each nerve fiber as opposed to about ten for singly innervated fibers. ${ }^{32}$ The reason for their existence seems clear, ie, multiply innervated muscle fibers are needed for smooth, slow, tremor-free eye movements.

The maximum force evoked by succinylcholine chloride at the estimated primary-position length was approximately $25 \mathrm{~g}$. Extrapolated to all four rectus muscles, ${ }^{7}$ this would correspond to an approximately $10-\mathrm{mm} \mathrm{Hg}$ retrobulbar and, hence, bulbar pressure rise, assuming an effective crosssectional area of the globe and adnexa of $7 \mathrm{~cm}^{2}$. Keeping the residual contraction after six minutes in mind, it seems well advised to wait at least ten minutes after a succinylcholine chloride injection before opening the eye for intraocular surgery.

Straight and parallel lines, such as those we found for succinylcholinestimulated eye muscles, were also seen in the experiments of Collins et $\mathrm{al}^{2}$ and Robinson et al. ${ }^{3}$ In their studies, both singly and multiply innervated fibers were measured, as innervation was changed by letting the patients fixate various targets with the other eye. Moreover, straight and parallel lines were also found by Lennerstrand ${ }^{33}$ on electrical stimulation of the retractor bulbi muscle of the cat, a muscle known to contain only singly innervated muscle fibers. It appears that stimulation of all eye muscle fibers, of multiply innervated muscle fibers, or of singly innervated muscle fibers results in linear and parallel length and tension curves.

In passive horizontal eye movement in awake volunteers, we found a linear 
relation between tension and eye rotation. We previously described a similar linear relation in passive cyclotorsion. ${ }^{4.5}$ As in those experiments, the constant slope values differed considerably for each volunteer (Table 2). We found an average of $0.91 \mathrm{~g} /$ degrees (range, 0.52 to $1.26 \mathrm{~g} /$ degrees), confirming the report of Collins et al. ${ }^{1}$ They found $1.048 \mathrm{~g} /$ degrees for pulling the eye nasally and $0.942 \mathrm{~g} /$ degrees for pulling the eye temporally from $30^{\circ}$ of abduction to $30^{\circ}$ adduction, or vice versa (range, 0.77 to $1.40 \mathrm{~g}$ / degrees), while the other eye fixated a

1. Collins CC, Carlson MR, Scott AB, et al: Extraocular muscle forces of normal human subjects. Invest Ophthalmol Vis Sci 1981;20:652-664.

2. Collins CC, Scott AB, O'Meara DM: Elements of the peripheral motor apparatus. $A m J$ Optom 1969;46:510-515.

3. Robinson DA, O'Meara DM, Scott AB, et al: Mechanical components of human eye movements. J Appl Physiol 1969:26:548-553.

4. Simonsz HJ: Investigations of Ocular Counterrolliny and Bielschowsky Head-Tilt Test, Stiffness in Passive Ocular Rolling and Displacement of Recti Eye Muscles, dissertation. Amsterdam, 1984.

5. Simonsz HJ, Crone RA, de Waal BJ, et al: Measurement of the mechanical stiffness in cyclotorsion of the human eye. Vision Res 1984;24:961-968.

6. Robinson DA: A quantitative analysis of extraocular muscle cooperation and squint. Invest Ophthalmol Vis Sci 1975;14:801-825.

7. Simonsz HJ, Härting F, de Waal BJ, et al: Sideways displacement and curved path of recti eye muscles. Arch Ophthalmol 1985;103:124-128.

8. Kaneko H, Koga A, Adachi K: Quantitative designation of the forced duction test: I. Difference between normal and pathological extraocular muscles. Acta Soc Ophthalmol J.pn 1971;75:1515-1523.

9. Madroszkiewicz M: Oculomyodynamometry: The strength and work of extra-ocular muscles in squint. Ophthalmologica 1970;161:491-498.

10. Metz HS, Cohen G: Quantitative forced traction measurements in strabismus, in Reinecke RD (ed): Strabismus II: Proceedings of the Fourth Meeting of the International Strabismus Association, Asilomar. New York, Grune \& Stratton, 1984 , pp 755-766.

11. Roth A: Les choix et le dosages opératoires en cas de strabismes dits concomitantes, in Berard PV, Quéré MA, Roth A, et al (eds) Chirurgie des strabismes. Paris, Masson, 1984, pp 188-204. target. If we compare these results with ours in the improved Robinson computer model, we find that they are fully compatible, as stiffness is slightly less when the eye muscles are innervated for $5^{\circ}$ of adduction compared with $30^{\circ}$ of adduction or abduction.

We found smaller differences between contralateral eyes and between measurements taken at different times. We originally thought that patient 1 had high values because of his exophoria. Exercise causes the length and tension curve to steepen. However, we found no significant

\section{References}

12. Schillinger RJ: The prevention of overcorrection and under-correction in horizontal strabismus surgery. $J$ Pediatr Ophthalmol 1966;3:38-41

13. Scott AB, Collins CC, O'Meara DM: A forceps to measure strabismus forces. Arch $O p h$ thalmol 1972;88:330-332.

14. Stephens KF, Reinecke RD: Quantitative force duction. Ophthalmology 1967:71:324-328.

15. Strachan IM, Brown BH, Johnson SG, et al: An apparatus for measuring forces in strabismus, in Moore S, Mein J, Stockbridge L (eds): Orthoptics: Past, Present, Future. New York, Grune \& Stratton, 1976, pp 123-128.

16. Rosenbaum AL, Meyer JH: New instrument for the quantitative determination of passive forced traction. Ophthalmology 1980;87:158163 .

17. Lang J, Horn T, von den Eichen U: Utber die ausseren Augenmuskeln und ihre Ansatzzonen. Gegenbaurs Morphol Jahrb 1980;126:817-840.

18. Fung YCB: Elasticity of soft tissues in simple elongation. Am J Physiol 1967;213:15321544

19. Pinto JG, Fung YCB: Mechanical properties of the heart muscle in the passive state. J Biomech 1973;6:597-616.

20. McMahon TA: Muscles, Reflexes and Loco motion. Princeton, NJ, Princeton University Press, 1984, pp 8-9

21. Duke-Elder WS, Duke-Elder PM: The contraction of the extrinsic muscles of the eye by choline and nicotine. Proc $R$ Soc B 1930;107:332343.

22. Bach- $y$-Rita $P$, Lennerstrand $G$, Alvarado $J$, et al: Extraocular muscle fibers: Ultrastructur al identification of iontophoretically labeled fibers contracting in response to succinylcholine. Invest Ophthalmol Vis Sci 1977;16:561-565.

23. Asmussen G: The properties of the extraocular muscles of the frog. Acta Biol Med Germ 1978;37:301-333.

24. Asmussen G: Morphologische, physiol- change in stiffness after patching one eye for two days.

This work was supported by the Alexander von Humboldt Foundation, Bonn, West Germany (Dr Simonsz)

We would like to thank R. A. Crone; I. Klinger and her staff; F. Salomon, $\mathrm{PhD}$, and $\mathrm{E}$. Grimm, $\mathrm{PhD}$, anesthesiologists, and their staff for their kind cooperation; J. M. Schmitt, G. Schwerdtfeger, C. Schuy, U. Jung, PhD, T. Krzizok, MD, and V. Hessemer, PhD, for volunteering; E. Steinmetz and R. Eckstein for art work; and D. A. Robinson, $\mathrm{PhD}, \mathrm{R}$. D. Reinecke, $\mathrm{MD}, \mathrm{PhD}, \mathrm{G}$. Kommerell, $\mathrm{MD}, \mathrm{PhD}$, F. Dreyer, $\mathrm{MD}, \mathrm{PhD}$, and especially G. Asmussen, $\mathrm{PhD}$, for their valuable suggestions. ogische und pharmakologische Eigenschaften der äusseren Augenmuskeln und ihre Veränderungen nach Denervation, dissertation. Leipzig, 1978.

25. Vilis T, Lennerstrand G, Outerbridge JS: Mechanical properties of succinylcholine-activated muscle fibers in the inferior oblique muscle of the cat. Acta Ophthalmol 1978;56:417-430.

26. Asmussen G, Kiessling A, Wohlrab F: Histochemische Charakterisierung der verschiedenen Muskelfasertypen in den äusseren Augenmuskeln von Säugetieren. Acta Anat 1971;79:526545.

27. Alvarado JA, van Horn C: Muscle cell types of the cat inferior oblique, in Lennerstrand $G$, Bach-y-Rita P (eds): Basic Mechanisms of Ocular Motility and Their Clinical Implications. Elmsford, NY, Pergamon Press Inc, 1975, pp 15-43.

28. Brooke $\mathrm{HH}$, Kaiser KK: Muscle fiber types: How many and what kind. Arch Neurol 1970;23:369-379.

29. Kiessling A, Asmussen G, Gornig $\mathrm{H}$ : Nichtfortgeleitete Potentiale im Elektromyogramm der Augenmuskeln von Saugern. Acta Biol Med Germ 1975;34:791-803.

30. Gornig H, Asmussen G, Kiessling A: Vorkommen und Bedeutung monophasischer Potentiale im Elektromyogramm der ausserer Augenmuskeln von Kaninchen und Katze. Graefes Arch Clin Exp Ophthalmol 1975;196:159-167.

31. Yamanaka Y, Bach-y-Rita P: Conduction velocities in the abducens nerve correlated with vestibular nystagmus in cats. Exp Neurol 1968;20:143-155.

32. Mühlendyck H: The Size of the Motor Units in Reference to Eye-Muscle Fibers of Different Innervation: Proceedings of the Symposium of the Deutsche Ophthalmologische Gesellschaft, Freiburg. Munich, JF Bergmann Verlag, 1978, pp 17-26.

33. Lennerstrand G: Mechanical studies on the retractor bulbi muscle and its motor units in the cat. J Physiol 1974;236:43-55.

\section{Currently in Other AMA Journals}

\section{ARCHIVES OF INTERNAL MEDICINE}

Primary Chemotherapy for Localized Non-Hodgkin's Lymphomas With Diffuse

Histologic Characteristics

German A. Gomez, MD; Satyanarayan Reddy, MD; Ramachandra M. Krishnamsetty,

MD; Maurice Barcos, MD, PhD; Hector Nava, MD; Tin Han, MD; Howard Ozer, MD,

PhD; Edward S. Henderson, MD (Arch Intern Med 1986;146:1785-1788) 